Revised Version

November 12, 2012

\title{
IS THE GOLDEN AGE OF THE PRIVATE RESEARCH UNIVERSITY OVER?
}

by

\section{Ronald G. Ehrenberg*}

(To be presented at the Federal Reserve Bank of New York/New York University Education Seminar, November 29, 2012))

* Irving M. Ives Professor of Industrial and Labor Relations and Economics at Cornell University and Director of the Cornell Higher Education Research Institute (CHERI). CHERI receives financial support from the Andrew W. Mellon Foundation and I am grateful to the Foundation for its support. An earlier version of this talk was presented at Emory University in October 2012. 


\section{$\underline{\text { Introduction }}$}

I received my $\mathrm{PhD}$ in June of 1970 graduating during one of the best job markets ever known to an academic. I had my choice of positions at literally a dozen major research universities and I felt that I was in heaven. Then, over the next decade, with rampant inflation and high unemployment rates, the average salaries of faculty teaching at America's colleges and universities fell by over $25 \%$ in real terms.

Perhaps this turn of events will make you wonder about how accurate my predictions today about the future of America's private research universities are likely to be. However, I want to begin by assuring you that after almost 30 years of conducting research on the economics of higher education and chairing faculty budget committees at Cornell, serving as a Cornell vice president and then as a trustee of both Cornell and the SUNY, and being associated with more national commissions and higher education organizations than I can count, that I know a lot more about higher education today than I did back in 1970. So I hope you will ponder carefully the things that I am going to say.

In spite of the dip in salaries in the 1970s, my career has coincided with the golden age of selective private research universities. Over the last 40 years our institutions have been transformed. Our undergraduate admissions have become increasingly selective and there has been a concentration of top undergraduate students from around the country and the world at our institutions. The growth of federal research funding has permitted our research activities to soar and many of us are teaching fewer courses today than our counterparts did in the past. Faculty salaries have grown increasingly disperse across institutions and average faculty salaries at the selective 
private research universities now far out distance those at most other institutions. ${ }^{1}$ Being a faculty member at a selective private research university has been, and still is, a great gig.

However, we now face a very troubled external environment. On the one hand, politicians and the public view us a part of the solution to our nation's problems. They understand that a highly educated population is essential in an internationally competitive knowledge based economy if we are to improve our nation's standard of living. However, the U.S no longer leads the world in terms of the share of our young adult population with college degrees and the groups in our population that are growing the most rapidly (people of color and from relatively low income families) are the groups that have historically been under represented in higher education. Although most American college students are educated in public higher education institutions, private research universities are expected to be part of the solution and to educate more undergraduate students. Increasingly we are also seen as major drivers of economic activity and the nation looks to us and our public sector counterparts to provide the research that will lead to the creation of new industries, high paying jobs, and improvements in our nations' economy, health, environment and food supply.

On the other hand, we are viewed as part of the problem. There is concern that our ever increasing tuition levels are limiting access to higher education and contributing to sky rocketing student debt burdens. There is concern that in spite of many of us having need blind admissions and need based financial aid policies that relatively few students from families with modest means attend our institutions. There is concern that we have amassed great endowments and don't spend enough from them to hold tuition down and

\footnotetext{
${ }^{1}$ Ehrenberg (2003)
} 
provide sufficient financial aid. So increasingly, our institutions worry about federal policies being imposed that would affect our ability to raise tuition, to force us to spend more from our endowments than we want, and maybe even that would cause us to lose some of the favorable tax treatment that we receive on our endowments and that donors receive when they make contributions to us.

What I hope to convince you today is that the financial models that private research universities operate under is under great stress and is breaking down. I am going to briefly state four reasons for this conclusion and then provide more details about each:

1. Our tuition levels have increased at rates that were 3 to $3.5 \%$ more than the rate of inflation for the last 30 years, but we have reached the point where economic and political forces will limit our ability to raise tuition in the future

2. Our financial aid budgets have dramatically increased, partially because of the great recession, but partially because of the policies we have pursued to make ourselves more accessible to students from families with limited means. The typical private research university now gives back more than $40 \%$ of each dollar that it takes in in undergraduate tuition in the form of financial aid. For most of us, undergraduate tuition is the major sources of unrestricted operating revenue and this limits our ability to fund our operating budgets.

3. The share of our ever increasing research budgets that are funded out of our own internal funds nationwide grew from around $10 \%$ in 1970 to about $20 \%$ in 2000 and has stayed roughly at that level since then. Although we talk about how full paying students (students who receive no institutional grant aid) are paying far less than the cost of their education, such a conclusion is based upon our 
including estimates of the value of the services provided by our buildings (which were often funded by gifts) into the calculation. In truth we may well be subsidizing research out of undergraduate tuition dollars. As federal funding for research becomes scarcer, we will increasingly have to turn to other external sources or to our internal funds to support research and/or we will have to reduce our commitment to research. Popular backlash to our funding research out of undergraduate tuition revenues will grow and it will be difficult for us to continue to do this.

4. During the last 20 to 30 years, our instructional costs have declined relative to almost every other category of expenditures including student services and administration. While partially this reflects a shift at many research universities to increased use of part-time and full-time nontenure track faculty in instruction, we need to dramatically reduce our administrative cost structures. A number of major universities have taken steps to do so, but these actions are not a panacea and often impost costs on faculty.

Moreover, all of these things are occurring at a time when many financial analysts predict that endowment returns in the years ahead will be lower than those that our institutions grew to expect in the years prior to the financial meltdown. Put simply, our institutions cannot count on high endowment returns to help alleviate our financial problems.

\section{$\underline{\text { Tuition }}$}

1. Over the last three decades undergraduate institutions grew by an average of 3.0 to $3.5 \%$ a year more than the rate of inflation. Tuition increases at our institutions 
have been associated with increases in expenditures per students in real terms. Put simply our students were paying more but also getting more. These increases have been driven by

a. Our aspirations to be the very best we can in every dimension of our activities, both academic and nonacademic (cookie monster analogy). ${ }^{2}$ As I will explain below this helps to explain why our administrative costs have continued to grow

b. Student and parents perceptions that where you go to college matters almost as much as whether you go to college and the belief that we confer unique educational and economic advantages on our students. As a result the size of our applicant pools keeps increasing and there have been historically only limited market forces to constrain our tuition growth

c. The USNWR rankings in which expenditure per student plays an important role. Any university that increased expenditures by a slower rate than its competitors would fall in the rankings. ${ }^{3}$

d. Growth of technology that we must provide to our students even if it increases our costs because they need to have familiarity with these technologies in the world of work and because we need to keep up with our competitors' provision of these technologies (ARMS RACE OF SPENDING)

But we may well have reached the point where raising tuition by rates similar to the past is becoming increasingly politically and economically unfeasible

\footnotetext{
${ }^{2}$ Ehrenberg (2002)

${ }^{3}$ Ehrenberg and Monks (1999)
} 


\section{Under graduate Financial Aid}

From the start of recorded history (which for our purposes is the early $20^{\text {th }}$ century), tuition at selective private colleges and universities was increasing at rates faster than inflation. But prior to 1980 many institutions had the discipline to link tuition increases to changes in median family income. For example, as I showed in my book Tuition Rising, Cornell's tuition was roughly $28 \%$ of median family income between 1965 and $1980 .^{4}$ (THIS WAS AN EXPLICIT POLICY AT CORNELL BACK IN THE LATE 70s) However, after 1980 as real income growth stagnated, our institutions focused on what our revenue needs were, not what families capacities to pay were and over time, our tuitions rose considerably relative to median family income. By 2010-2011, for example, Cornell's tuition was $65 \%$ of median family income and after declines in real family income over the last two years, today it is certainly even higher.

It should not be surprising then that the financial need of our students increased over time and that our tuition discount rate (the share of each dollar of tuition that we give back in the form of financial aid) grew. Our financial aid policies also grew more generous as many of our institutions experienced periods of prolonged and substantial increases in endowment values. Many institutions aim to spend between 4 to 5 percent of a weighted average (usually over 3 years or 12 quarters) of their endowment values each year and with prolonged endowment growth, the percentage being spent relative to the current value of the endowment often turned out to be substantially less than 4 to 5 percent.

\footnotetext{
${ }^{4}$ Ehrenberg (2002)
} 
So over time, feeling plush, and realizing the relatively few Pell Grant recipients attended their institutions, the wealthiest institutions (Harvard, Yale, Princeton, and Stanford) began to increase the generosity of their financial aid policies and the rest of us followed suit to the best of our abilities, By the fall of 2008, the average tuition discount rate at private 4-year institutions nationwide had risen to 42 percent, up from $26.7 \%$ in the fall of 1990. Inasmuch as most of us fund the majority of our students' grant aid out of current revenues (at Cornell, with an endowment in the $\$ 5$ billion range, we fund over $80 \%$ of our aid this way), our financial aid budgets consume an increasing share of the increase in tuition revenue that we generate each year.

The bottom fell out when the Senate Finance Committee began to investigate the endowment spending policies of the institutions with the largest endowments in 20072008. Concerned about why the wealthy institutions kept increasing tuitions while their endowments grew, the Committee wanted to know why we could not spend a greater share of our endowments both to hold tuition increases down and to increase financial aid. Fear that the Committee would propose regulations that would require us to spend a minimum fraction of our endowment value each year that exceeded what we planned to spend led the richest institutions to eliminate all loans from their financial aid policies and increase the generosity of their grant aid programs even more. Again the rest of us reacted to the best of our abilities.

But we did not see the financial collapse coming which wreaked havoc with our endowments and simultaneously and dramatically increased the financial need of our applicants. As a result our tuition discount rates have increased even further. For example, if I read Emory University’s Annual Operating Plan for Fiscal Year 2012-2013 correctly, 
its revenue from students (tuition and student fees) was projected to increase by $\$ 32.8$ million in 2012-2013 and its financial aid costs were projected to increase by $\$ 21.5$ million. ${ }^{5}$ Put simply at the margin Emory was projecting that it would be giving back almost 2/3 of each additional tuition dollar that it planned to receive in the form of financial aid this year. ${ }^{6}$

While the situation will improve somewhat if family incomes start growing again, it seems clear that our current financial aid policies are not sustainable. An added complication is that at most of our institutions, the share of our students who receive grant aid from the university keeps rising. At Cornell, for example, in 1987-88 about 29\% of our undergraduate students received grant aid averaging $\$ 5,300$ from the university; this year the university projected that almost $52 \%$ of our students will receive an average of more than $\$ 34,000$ in grant aid from us. Over time fewer and fewer of our students, given our financial aid policies, pay full tuition. As information seeps out to full paying students how large the grant aid is that some of their less financially fortunate counterparts are receiving and how many of the latter there are, financial aid potentially becomes a very divisive issue on campus. In the future, full-paying students are less likely to have warm feelings about their Alma Mater.

All around the country university leaders are responding by mounting campaigns to raise endowments for undergraduate financial aid. Hopefully their efforts will be successful. But the magnitudes of the sums needed are enormous and, if successful, they may displace funds that could have been raised for other purposes.

\footnotetext{
${ }^{5}$ Office of the Provost and Executive Vice President for Academic Affairs, Emory University Annual Operating Plan Fiscal Year 2012-2013 (May 31, 2012), p. 11

${ }^{6}$ These figures may refer to both undergraduate and graduate tuition and financial aid
} 


\section{The Costs of Research}

Between roughly 1970 and 2000, the share of our rapidly growing total university research and development expenditures nationwide financed out of internal university sources increased from about $11 \%$ to over $20 \%$ and it has remained in the $20 \%$ range since then. In part, this increase reflected the growing costs of startup cost packages provided to new faculty hires in STEM fields. A survey we did at CHERI over a decade ago found that the typical startup cost package at private research universities was in the $\$ 400,000$ to $\$ 500,000$ range for assistant professors and in the $\$ 1$ million to $\$ 2$ million range for full professors; both ranges are certainly much higher today. ${ }^{7}$ Startup cost packages for faculty without federal research funding cannot be recovered in indirect cost billings.

In part, the increase reflects the fact that the federal government has set maximum limits for several categories of indirect cost recoveries (now called facilities and administration costs) which are far below what universities actually spend. In part it is because the indirect cost recovery formulas have historically assumed a longer useful life for research building than actually occurs (which restricts the annual depreciation allowance that the university can collect on these buildings each year). And in part it is because external research funders sometimes require institutional matching funds to be included in grant proposals. As research volumes increased, the dollar impact of these institutional research expenditure on private research university budgets grow.

Where do internal university funds spent on research come from? In part they come from unrestricted endowment spending and in part they come from annual giving

\footnotetext{
${ }^{7}$ Ehrenberg, Rizzo and Jakubson (2007)
} 
from private sources that can be used for current operating expenses or for capital purchases. In part, they may come from revenue streams that the university has developed from the commercialization of its faculty members' research findings (licensing revenue from patents and startup company investments). But in part, they may come from other sources of unrestricted revenues in the operating budget, namely undergraduate tuition.

In research I published a few years ago, colleagues and I asked "who actually bears the burden of increasing university expenditures on research from institutional funds?” Our econometric analyses suggested that as internal university research funding per faculty member increased at private research universities, holding other factors constant, that there was an increase in student-faculty ratios, a substitution of lecturers for professional rank faculty (more undergraduate teaching done by nontenure track faculty), an increase in average faculty salaries (presumably to attract top researchers), and an increase in undergraduate tuition levels. ${ }^{8}$ The magnitudes of these effects were not that large, but they do suggest that some of the costs of our institutional expenditures on research are being borne directly by our undergraduate students. Whether these costs are more than offset by the benefits that our undergraduate students receive from being educated in proximity to researchers who are at the cutting edge of their disciplines is an open questions and in the years ahead it will continue to be important for our great research universities to emphasize the role that research plays in our undergraduate students education.

But as tuition keeps rising, student debt levels keep increasing, and we begin to spend more out of our institutional funds on research to make up for the likely failure of

\footnotetext{
${ }^{8}$ Ehrenberg, Rizzo and Jakubson (2007)
} 
federal funds for research to grow in the years ahead, unless we develop substantial new external funds to support our research, inevitable undergraduate students will be bearing more of the cost of our research enterprise. This may not be sustainable.

\section{Are Instructional Expenditures Being Crowded Out by Student Service and}

\section{Administrative Expenditures?}

During the 1987-2008 period the share of resources going to instructional expenditures at private research universities declined relative to the share of resources going to student services, academic support and institutional support. Data from the Delta Cost Project suggest that during the period instructional expenditures grew at our institutions by about 1.87 percent a year more than the rate of inflation, while student service expenditures, academic support expenditures, and institutional support expenditures grew, respectively, by 3.13 percent, 2.87 percent, and 2.6 percent a year more than the rate of inflation. ${ }^{9}$ Why did this shift in our allocation of our resources away from our core teaching mission occur?

Student service expenditures include the costs of admissions, registrar activities, and activities whose primary purpose is to contribute to students emotional and wellbeing outside the classroom. While some critics of higher education view these expenditures as frills that make no direct contribution to students persistence in, and graduation from, college, research by one of my students and me suggests that they have positive effects on persistence and graduation rates, especially for students from disadvantaged educational and economic backgrounds. ${ }^{10}$ So I would be cautious before arguing that they have been growing too rapidly at our institutions.

\footnotetext{
${ }^{9}$ Ehrenberg (2012), table 4

${ }^{10}$ Webber and Ehrenberg (2010) and Webber(2012)
} 
Academic support expenditures include expenditures that support instruction, research and public service, including libraries, museums, academic computing, and academic administration. The rapid growth of expenditures in this category derives at least partially from our adopting costly technology to enhance student learning and faculty research and to provide students with tools they will need to compete in the job market. $^{11}$

Institutional support expenditures include many of the administrative functions of the university including legal, audit and risk management, human resources, budget, alumni affairs and development, and public and governmental relations. It is this category of expenditures that critics of our institutions, including faculty critics, focus on when they talk about "administrative bloat". ${ }^{12}$ While some of these administrative cost increases can be chalked up to a proliferation of governmental regulations and reporting requirements and others to the fact that it takes spending money to make money (alumni relations and development), I believe the growth of administrative expenditures can also be chalked up to every unit on campus seeking to be as good as it can in every dimension of its activities (my cookie monster analogy revisited).

Prior to the financial meltdown, our institutions tended to compare their expenditures in different functional categories to what their competitors were doing. So, for example, an institution would hire an external consultant to do a study of its human resource division's expenditures relative to its competitors'. If the report came back that the institution was spending less than its competitors, the vice president of human resources would stress to the president and the CFO all the wonderful things the

\footnotetext{
${ }^{11}$ Archibald and Feldman (2011)

${ }^{12}$ Ginsberg (2011)
} 
institution could do for faculty and staff with more resources (employee assistance programs, educational programs to facilitate employee advancement, financial counseling for retirement, spousal employment search support, subsidized child care centers). So in a manner similar to the comparability studies done on executive compensation in the corporate world, this led to a built in bias to increase administrative expenditures, because being below the mean in an expenditure category was a signal that more money should be spent that area.

Only after the financial meltdown, did many institutions realize they had to view administrative costs more systematically across the whole university. A number of institutions hired management consulting companies to provide advice to them (and public cover for hard decisions that would cost people their jobs). UNC, Cornell and Berkeley all contracted with Bain Consulting and the advice that came back was pretty much the same for all three institutions (WHAT A GREAT BUSINESS MODEL) ${ }^{13}$ :

1. Reduce layers of administration and increase the number of direct reports that each administrator supervises

2. Centralize procurement and limit purchasing to "preferred vendors" to achieve price concessions from suppliers due to large scale purchasing. Also move more fully to electronic purchasing to reduce the paperwork involved (dramatically reducing employment)

\footnotetext{
${ }^{13}$ The question arises as to why didn't the universities that hired Bain after the first university did so simply follow the advice given to the first university without employing the consultant. In part the answer is that hiring an outside consultant provides "cover" for the administration when it needs to make painful decisions (layoffs). In part, it is because of the fear that there are some unique issues that each university is facing. And in part, it is because the consultants who design the strategies often are later hired to help implement them.
} 
3. Achieve efficiencies in how information technology is delivered and organized across the campus and similarly reorganize the delivery of support services such as finance, communication and human resources (Does every college on campus need its own tech support group, does every college need its own director of human resources etc.)

At Cornell, we are on track at our Ithaca campus to achieve savings of $\$ 75$ to $\$ 85$ million a year by the end of FY2015 from these efforts; this represents more than 5\% of our operating budget once one removes external research funding. However, two cautions are in order. First, these are one time cuts in the university's base operating budget; continual efforts to reduce both administrative and other costs will be necessary if Cornell and other private research universities are to have any hope of reducing their rates of budget and tuition increases.

Second, cost savings may be in the eyes of the beholder. Shifting to electronic purchasing and reducing clerical support puts more burdens on faculty time. Establishing preferred vendor relationships and requiring faculty to make purchases through them does not necessarily mean that faculty can get the lowest possible price in the shortest possible time for the specific items that they want. A number of scientists at Cornell have vigorously complained to me about Cornell's movements in this direction. What Will the Future Bring?

Permit me to briefly conclude with some speculations on what the future will bring for us. At many private research universities a large fraction of the introductory teaching is already done by non-tenure track faculty, which some research, including my 
own, suggests has an adverse effect on student outcomes. ${ }^{14}$ We need to figure out ways to use technology to simultaneously reduce instructional costs and improve educational outcomes, especially in large introductory classes. Although MOOCs are the in vogue now, and many universities are trying to figure out how they will effect things in the future, the careful work of the National Center for Academic Transformation (NCAT) and the Carnegie Mellon University Open Learning Initiative (OLI) both suggest that introductory classes in a wide variety of subject matter areas can be redesigned with the use of technology to promote active learning, enhanced course persistence, and to reduce costs. Such a movement is often not supported by faculty (especially senior people like me) who either do not want to put the time into completely restructuring how they offer classes or who worry that the savings that are achieved will result in smaller departmental sizes and fewer colleagues.

In addition to changing how we teach our classes, we need to understand that no great research university can offer instruction in every subject, or every specialty area in subjects that it does offer. Our research universities need to figure out ways to share classes with competitors either using synchronous (such as this) or asynchronous technologies. As an example, every fall I teach a class on the economics of the university to one group of students in the room in Ithaca and another group in our Cornell-inWashington program using two-way video operated over the Internet. A number of years ago, I simultaneously taught the class to students at Cornell and to students at Binghamton University (my undergraduate school), to illustrate how universities can share specialized faculty resources (in this case me) to improve education.

${ }^{14}$ Ehrenberg and Zhang (2005) 
The quest for new revenues to keep our financial models going will take us more in the directions of seeking to increase flows of annual giving from external sources, to increase commercialization of our research, to improve usage of our facilities (through summer and evening operations), and to generate more revenue from full tuition paying professional degree programs, including hybrid and on-line programs. Many faculty members in arts and sciences at private research universities worry that these latter activities will depreciate our "brands" and take faculty time away from what they see as the core missions of the university- namely undergraduate education, doctoral education and research - so efforts by administrators to expand in these directions often lead exacerbate tensions between faculty and administrators. Speaking like an economist, I would urge faculty members to think of them as ways to shift our budget constraints out, which in the long run will permit us to do more of the things that we value the most.

In conclusion, I must stress that in spite of the somewhat pessimistic tone of my remarks, the financial challenges that selective private universities will face in the years ahead are actually relatively minor as compared to the challenges that our nation's great public research universities will face. ${ }^{15}$ A recent National Research Council committee, upon which I served, as well as a recent National Science Board report, details the financial and governance problems faced by the publics. ${ }^{16}$

\footnotetext{
${ }^{15}$ Ehrenberg (2006) discusses the problems faced by public higher education prior to the "great recession"; things have only gotten worse since then.

${ }^{16}$ National Research Council (2012) and National Science Board (2012)
} 


\section{Cited References}

Robert Archibald and David Feldman, Why Does College Cost So Much (New York NY: Oxford Univ. Press, 2011)

Ronald G. Ehrenberg, Tuition Rising: Why College Costs So Much (Cambridge MA: Harvard University Press, 2002)

Ronald G. Ehrenberg, “Studying Ourselves: The Academic Labor Market”, Journal of Labor Economics 21 (April 2003): 267-287

Ronald G. Ehrenberg, “The Perfect Storm and the Privatization of Public Higher Education”, Change 38 (Jan. /Feb. 2006): 38-46

Ronald G. Ehrenberg, “American Higher Education in Transition”, Journal of Economic Perspectives 26 (Winter 2012): 193-216

Ronald G. Ehrenberg, Michael J. Rizzo, and George H. Jakubson, “Who Bears the Growing Cost of Science at Universities”, in Paula E. Stephan and Ronald G. Ehrenberg eds. Science and the University (Madison WI: University of Wisconsin Press, 2007)

Ronald G. Ehrenberg and James Monks, “U.S. News \& World Report Rankings: Why Do They Matter?” Change 31(Nov/Dec 1999)

Ronald G. Ehrenberg and Liang Zhang, "Do Tenured and Tenure Track Faculty Matter?” Journal of Human Resources 40 (Summer 2005): 647-659

Benjamin Ginsberg, The Fall of the Faculty; The Rise of the All-Administrative University and Why It Matters (New York NY: Oxford Univ. Press, 2011)

National Research Council, Research Universities and the Future of America (Washington DC: National Academies Press, 2012) 
National Science Board, Diminishing Funding and Rising Expectations; Trends and Challenges for Public Research Universities (Arlington VA, National Science Foundation, 2012)

Douglas A. Webber. "Expenditures and Postsecondary Graduation: An Investigation Using Individual-Level Data from the State of Ohio, Economics of Education Review 31 (October 2012): 615-618

Douglas A. Webber and Ronald G. Ehrenberg, “Do Expenditures Other than Instructional Expenditures Affect Graduation and Persistence Rates in American Higher Education”, Economics of Education Review 29 (December 2010): 947-958 